\title{
Studying the Sensitivity of Satellite Altimetry, Tide Gauge and GNSS Observations to Changes in Vertical Displacements
}

\begin{abstract}
Tide gauge observations provide sea level relative to the Earth's crust, while satellite altimetry measures sea level variations relative to the centre of the Earth's mass. Local vertical land motion can be a significant contribution to the measured sea level change.

Satellite altimetry was traditionally used to study the open ocean, but this technology is now being used over inland seas too.

The difference of both observations can be used to estimate vertical crustal movement velocities along the sea coast. In this paper, vertical crustal movement velocities were investigated at tide gauge sites along the Adriatic Sea coast by analyzing differences between Tide Gauge (TG) and Satellite Altimetry (SA) observations. Furthermore, the estimated vertical motion rates were compared with those from nearby GNSS measurements.

The study determines the practical relationships between these vertical crustal movements and those determined from unrelated data acquired from the neighbouring GNSS stations. The results show general consistence with the present geodynamics in the Adriatic Sea coastal zone.
\end{abstract}

Keywords: GNSS, satellite altimetry, sea level, tide gauge, vertical crustal movements

Received: 26 March 2021; accepted: 29 June 2021

(C) 2021 Authors. This is an open access publication, which can be used, distributed and reproduced in any medium according to the Creative Commons CC-BY 4.0 License.

1 University of Warmia and Mazury in Olsztyn, Department of Geoinformation and Cartography, Olsztyn, Poland, email: katarzyna.pajak@uwm.edu.pl (corresponding author),

ORCID ID: https://orcid.org/0000-0003-0697-8547

2 University of Warmia and Mazury in Olsztyn, Department of Geoinformation and Cartography, Olsztyn, Poland, email: kamil.kowalczyk@uwm.edu.pl,

ORCID ID: https://orcid.org/0000-0001-7428-6097

3 Riga Technical University, Department of Geomatics, Rīga, Latvia, email: janis.kaminskis@rtu.lv, ORCID ID: https://orcid.org/0000-0001-6345-8084

4 University of Warmia and Mazury in Olsztyn, Department of Geoinformation and Cartography, Olsztyn, Poland, email: magdalena-idzikowska@wp.pl 


\section{Introduction}

Coastal sea level is impacted by many factors, including astronomical, atmospheric, oceanic and the land motion processes of the Earth. These processes vary over a wide range of timescales and can interact with each other, making the prediction of coastal sea level a very challenging task [1]. Furthermore, sea level monitoring is currently a hot topic for research, e.g., [2-5]. The interest in global sea level rise (GSLR) monitoring is growing rapidly due to a concomitant increasing awareness of global climate change [6].

A useful data series for sea level change are the sea-level records taken at tide gauges (TG). Tide gauges measure the sea level height with respect to the land upon which the tide gauge benchmarks are grounded [7]. However, there are major questions concerning the reasons behind sea level rise and especially whether it is due to local land subsidence at the coast or sandy erosion.

To complement these observations and to acquire a more complete view of the open ocean, the technique of satellite altimetry is often implemented. The difference between the altimetry and TG data is the absolute vertical ground motion [8, 9].

The main aim of this paper was vertical crustal movement analysis based on satellite altimetry, tide gauge and GNSS data. Vertical crustal movements have considerable consequences for those monitoring sea level changes, therefore it was the main reason for our choice of research topic.

We used the difference time series SA-TG and examined its long-term behaviour at time scales. Also, vertical crustal movements in nearby GNSS stations were also determined. The obtained results were compared with the results of the calculations based on the difference time series SA-TG.

\section{Data Sets and Methods}

In this study, vertical crustal movements were investigated using the differences between SA and TG monthly sea level time series at each TG station along the Adriatic Sea coast. The change trends in mean sea level were determined from TG observations and SA data. Vertical crustal movements in nearby GNSS stations were also determined.

The time series of satellite altimetry and tide gauge has a seasonal signal, therefore the annual, semi-annual and 18.6-year cycles were investigated. The 18.6-year cycle is a lunar nodal cycle, caused by the relative movements of the Moon. This important precession of the Moon, namely, the 18.61-year lunar nodal cycle, causes tidal modulations on interannual time scales. These modulations affect the interpretation of tide gauge records that extend over several years, particularly when dealing with water level extremes [10]. The obtained time series from tide gauge and satellite altimetry was decomposed, with a linear trend and trend error determined. The linear regression method and Fourier analysis were employed. 


\section{Tide Gauge Data}

The time series from each month available along the Adriatic Sea coast was taken from the "revised local reference (RLR)", which can be found on the Permanent Service for Mean Sea Level (PSMSL). The RLR is the most appropriate tide gauge data set for long-term trend sea level studies [11]. This study used available time series from tide gauge observations at various time intervals (Fig. 1, Tab. 1). The time series are from 24 to 64 years with a monthly time resolution. In the real data time series, to get an accuracy of $0.1 \mathrm{~mm} /$ year we need 100 years. In the data time series without seasonal variations, to get an accuracy of $0.1 \mathrm{~mm}$ per year we need 49 years [12].

The selected area was highlighted with the red line in the map from PSMSL website.

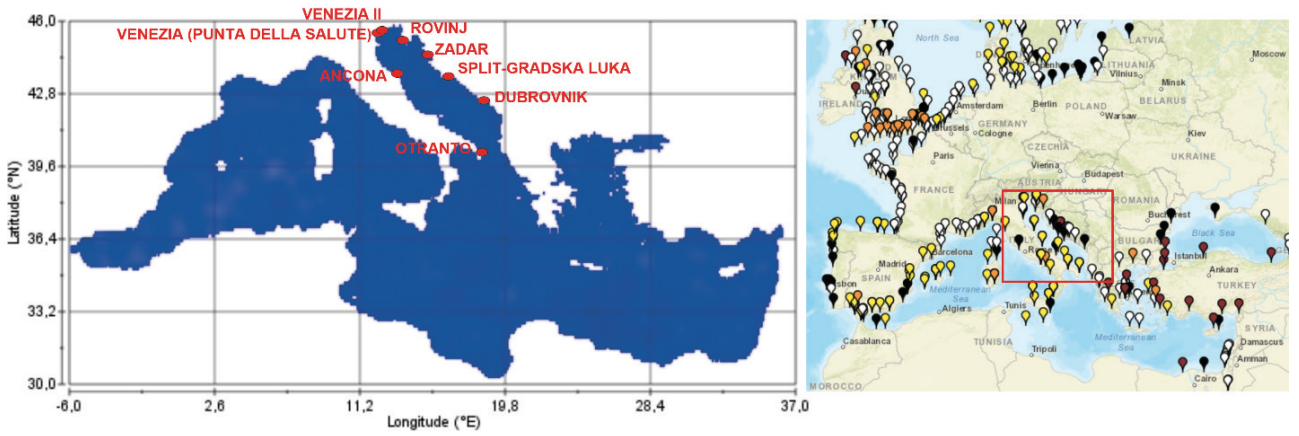

Fig. 1. Map of the TG data locations used in this study.

The selected TG sites are highlighted with a red circle

Source: own elaboration based on the data from Permanent Service for Mean Sea Level [13] website

Table 1. Description and locations of tide gauge and nearby GNSS network, the period of processed data

\begin{tabular}{|l|c|c|c|c|c|c|c|c||}
\hline $\begin{array}{c}\text { Name } \\
\text { station }\end{array}$ & $\begin{array}{c}\text { Station } \\
\text { ID }\end{array}$ & $\begin{array}{c}\text { Latitude; } \\
\text { Longitude }\end{array}$ & Country & $\begin{array}{c}\text { Time } \\
\text { span }\end{array}$ & $\begin{array}{c}\text { IGS-type } \\
\text { acronym }\end{array}$ & $\begin{array}{c}\text { Latitude; } \\
\text { Longitude }\end{array}$ & $\begin{array}{c}\text { Installed } \\
\text { date }\end{array}$ & Country \\
\hline \hline Dubrovnik & 760 & $\begin{array}{c}42.6583 ; \\
18.0633\end{array}$ & Croatia & $1956-2018$ & DUB2 & $\begin{array}{c}42.649986 ; \\
18.110431\end{array}$ & 12.12 .2011 & Croatia \\
\hline $\begin{array}{l}\text { Split- } \\
\text { Gradska } \\
\text { Luka }\end{array}$ & 352 & $\begin{array}{c}43.5067 ; \\
16.4417\end{array}$ & Croatia & $1954-2018$ & SPLT & $\begin{array}{c}43.5066452 ; \\
16.43844604\end{array}$ & 05.05 .2004 & Croatia \\
\hline Zadar & 1859 & $\begin{array}{c}44.1233 ; \\
15.235\end{array}$ & Croatia & $1994-2018$ & ZADA & $\begin{array}{c}44.113173 ; \\
15.227484\end{array}$ & 09.12 .2008 & Croatia \\
\hline Rovinj & 761 & $\begin{array}{c}45.0833 ; \\
13.6283\end{array}$ & Croatia & $1955-2018$ & PORE & $\begin{array}{c}45.226013 ; \\
13.595041\end{array}$ & 09.12 .2008 & Croatia \\
\hline
\end{tabular}


Table 1. cont.

\begin{tabular}{|c|c|c|c|c|c|c|c|c|}
\hline $\begin{array}{l}\text { Name } \\
\text { station }\end{array}$ & $\begin{array}{l}\text { Station } \\
\text { ID }\end{array}$ & $\begin{array}{l}\text { Latitude; } \\
\text { Longitude }\end{array}$ & Country & $\begin{array}{l}\text { Time } \\
\text { span }\end{array}$ & $\begin{array}{l}\text { IGS-type } \\
\text { acronym }\end{array}$ & $\begin{array}{l}\text { Latitude; } \\
\text { Longitude }\end{array}$ & $\begin{array}{l}\text { Installed } \\
\text { date }\end{array}$ & Country \\
\hline \multirow{2}{*}{ Venezia II } & \multirow{2}{*}{2100} & \multirow{2}{*}{$\begin{array}{l}45.418219 \\
12.426528\end{array}$} & \multirow{2}{*}{ Italy } & \multirow{2}{*}{ 2001-2015 } & VEN1 & $\begin{array}{l}\text { 45.43056944; } \\
12.35407778\end{array}$ & 01.08 .2008 & Italy \\
\hline & & & & & PSAL & $\begin{array}{c}45.430717 \\
12.33652783\end{array}$ & 01.01 .2005 & Italy \\
\hline \multirow{2}{*}{$\begin{array}{l}\text { Venezia } \\
\text { (Punta } \\
\text { Della } \\
\text { Salute) }\end{array}$} & \multirow{2}{*}{168} & \multirow{2}{*}{$\begin{array}{l}\text { 45.433333; } \\
\text { 12.333333 }\end{array}$} & \multirow{2}{*}{ Italy } & \multirow{2}{*}{ 1909-2000 } & VEN1 & $\begin{array}{l}\text { 45.43056944; } \\
12.35407778\end{array}$ & 01.08 .2008 & Italy \\
\hline & & & & & PSAL & $\begin{array}{c}\text { 45.430717; } \\
12.33652783\end{array}$ & 01.01 .2005 & Italy \\
\hline
\end{tabular}

\section{Satellite Altimetry Data}

Gridded monthly sea level anomalies with a spacing of $0.25^{\circ} \times 0.25^{\circ}$ were obtained from the satellite multimission product of the Archiving, Validation, and Interpretation of Satellite Oceanographic [14] and from the Copernicus Marine and Environment Monitoring Service [15]. This data set was produced by combining data from several satellite altimetry missions and spans the period from January 1993 to December 2018. All the state-of-the-art geophysical corrections were applied.

Altimetric measurements were corrected for atmospheric effects (ionospheric delay and dry/wet tropospheric effects) and geophysical processes (solid, ocean, pole tides, loading effect of ocean tides, sea state bias, and the inverted barometer response of the ocean).
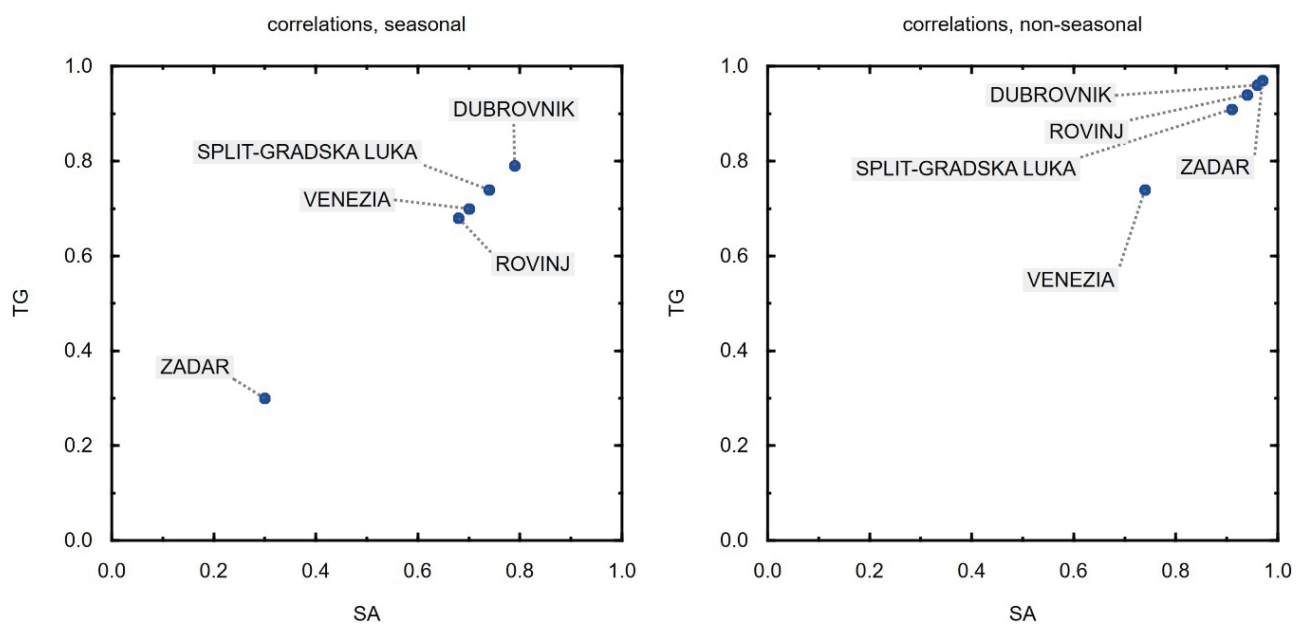

Fig. 2. Correlation coefficients between the satellite altimetry and tide gauge results for the seasonal and non-seasonal time series 
Detailed information on the corrections can be found on the AVISO and CMEMS website. The sea level was compared at geographical points, which the differences in satellite altimetry data sets and tide gauge data sets were investigated by the estimation of the correlations. The one producing the best agreement with tide gauges in terms of correlations was chosen. The results are presented in Figure 2.

\section{GNSS Data}

We used the measurements from a total of 6 GNSS stations which are co-located at or close to a TG station along the Adriatic Sea coast. The vertical coordinates time series of all GNSS stations were obtained from the Nevada Geodetic Laboratory NGL [16] and Sonel [17]. Time series are from 5 to 12 years with a daily time resolution (Fig. 3). Distance from the nearest TG: from $1 \mathrm{~m}$ to $16,069 \mathrm{~m}$.

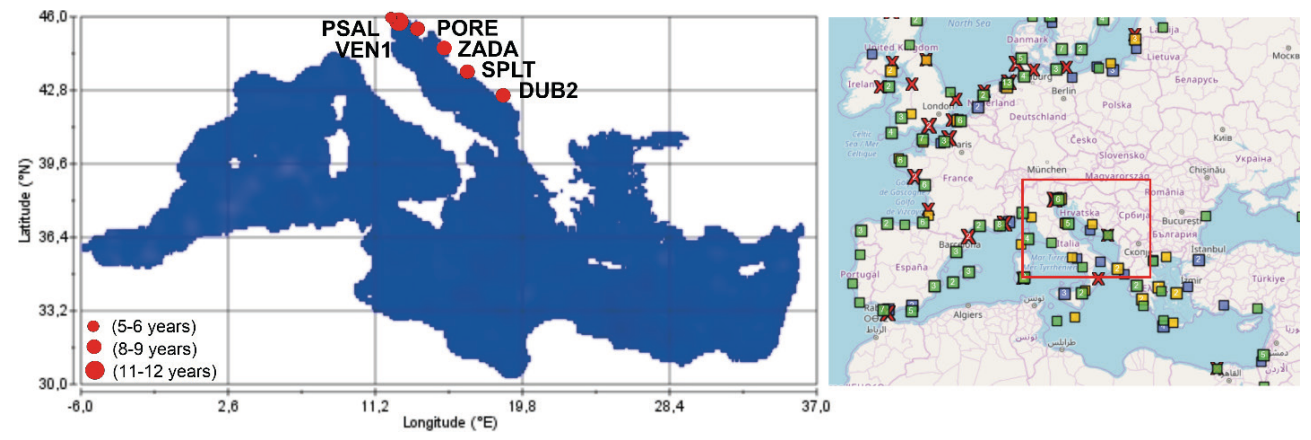

Fig. 3. Map of the GNSS data locations used in this study. The selected GNSS stations are highlighted with a red circle (marked time intervals of data - years of data). The selected area highlighted with a red line in the map is from the SONEL website

Source: own elaboration based on the data from SONEL [17] website

\section{Results}

\subsection{Estimation of Vertical Land Movements Combining TG and SA}

Two time periods were selected to estimate trends in mean sea level from the tide gauge records available along the coasts of the Adriatic Sea coastal zone. First, the shortest 1993-2018 period corresponds to the satellite altimetry data. In this period the sea level trend along the Adriatic Sea coast was from $3.12 \pm 0.31 \mathrm{~mm} /$ year to $+3.54 \pm 0.32 \mathrm{~mm} /$ year from the satellite altimetry data. While in this period the sea level trend along the Adriatic Sea coast was from $+1.08 \pm 0.25 \mathrm{~mm} /$ year to $+3.91 \pm 0.27 \mathrm{~mm} /$ year from the tide gauge data. However, the trend was estimated is similar to the global mean sea level rise of $+3.1 \pm 0.3 \mathrm{~mm} /$ year [3] . 
Second, the trend was computed from the series of monthly sea level differences for the other period, e.g. from 1909 to 2018 (from the TG data) and the period 1993-2018 (from the SA data). In addition, the time series should not contain outliers, effects of seasonality or data discontinuities, therefore they have been removed. Table 2 presents the sea level trend estimated based on the two different data sets.

Table 2. Sea level trends from satellite altimetry and tide gauge time series

\begin{tabular}{|c|c|c|c|c|c|c|}
\hline \multirow{2}{*}{ TG_Station } & \multirow{2}{*}{$\begin{array}{c}\text { SA } \\
\text { (from 1993 } \\
\text { to 2018) } \\
\begin{array}{c}\text { trend } \\
{[\mathrm{mm} / \mathrm{yr}]}\end{array}\end{array}$} & \multicolumn{2}{|c|}{$\begin{array}{c}\text { TG } \\
\text { (from beginning to 2018) }\end{array}$} & \multicolumn{2}{|c|}{$\begin{array}{c}\text { TG } \\
\text { (from } 1993 \text { to 2018) }\end{array}$} & \multirow{2}{*}{$\begin{array}{l}\text { Distance } \\
\text { SA to TG } \\
{[\mathrm{km}]}\end{array}$} \\
\hline & & time span & $\begin{array}{l}\text { trend } \\
{[\mathrm{mm} / \mathrm{yr}]}\end{array}$ & time span & $\begin{array}{c}\text { trend } \\
{[\mathrm{mm} / \mathrm{yr}]}\end{array}$ & \\
\hline Dubrovnik & $+3.12 \pm 0.31$ & 1956-2018 & $+1.52 \pm 0.07$ & 1993-2017 & $+3.91 \pm 0.27$ & 6.25 \\
\hline Split-Gradska Luka & $+3.54 \pm 0.32$ & 1954-2018 & $+0.96 \pm 0.06$ & 1993-2018 & $+2.68 \pm 0.25$ & 14.21 \\
\hline Zadar & $+3.48 \pm 0.34$ & - & - & 1994-2017 & $+2.75 \pm 0.30$ & 8.78 \\
\hline Rovinj & $+3.38 \pm 0.34$ & 1955-2018 & $+0.74 \pm 0.07$ & 1993-2018 & $+1.08 \pm 0.25$ & 4.64 \\
\hline Venezia & $+3.12 \pm 0.31$ & $\begin{array}{l}1909-2000 \\
2001-2015\end{array}$ & $+2.46 \pm 0.03$ & $\begin{array}{l}1993-2000 \\
2001-2015\end{array}$ & $+7.38 \pm 0.50$ & 6.26 \\
\hline Ancona & $+3.32 \pm 0.34$ & - & - & - & - & - \\
\hline Otranto & $+3.12 \pm 0.31$ & - & - & - & - & - \\
\hline
\end{tabular}

Because the linear trends of differences between tide gauge records and satellite altimetry data were to be computed, this study used a time series of 25 years (from January 1993 to December 2018), with only the time series for the Venezia and Zadar stations being shorter (Tab. 2). The Adriatic Sea is very well represented by long and good quality tide gauge records (from Dubrovnik to Venezia) [7]. Figure 4 presented the time series - on the left is the original observation data from the two sources; the middle column is those after the removal of the seasonal signals, the right column shows the respective non-seasonal SA-TG difference series (TG measures the sea surface height relative to the ground and the satellite altimetry measures the absolute sea surface height relative to the terrestrial reference frame with respect to which the satellite orbit is defined) [18]. 

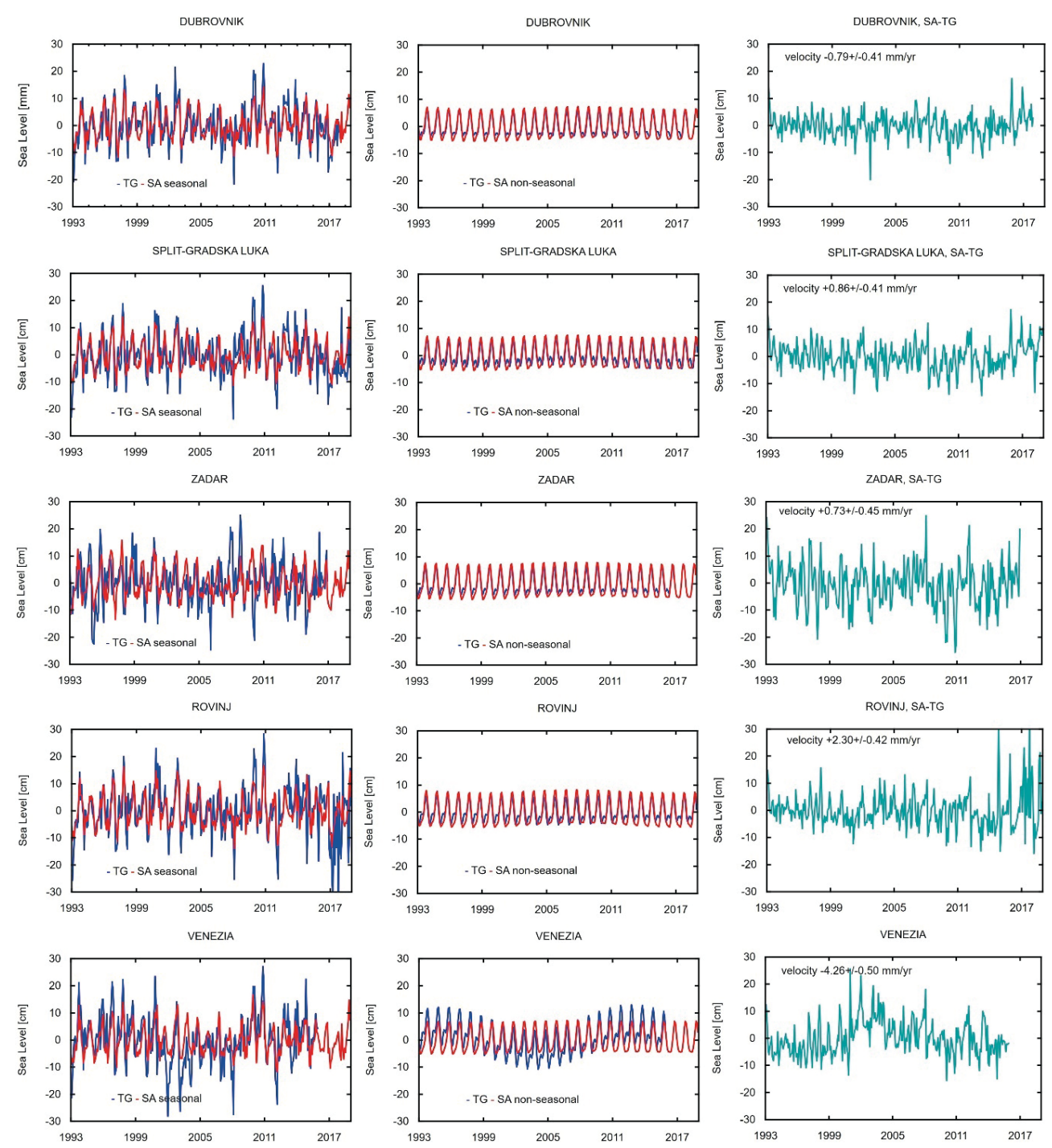

Fig. 4. Seasonal, non-seasonal and SA-TG non-seasonal time series.

The first and second columns show seasonal and not seasonal SA (red line) and TG (blue line) time series at Dubrovnik, Split-Gradska Luka, Zadar, Rovinj and Venezia stations.

The third column shows the non-seasonal SA-TG time series and the least-squared linear fit to give the velocity

The seasonal signals (annual, semi-annual and 18.6-year) from the original time series by simple subtraction of estimates obtained by least-squared fitting of seasonal sinusoids with annual, semi-annual and 18.6-year periods were removed. In general, good agreement can be observed between the two-time series, showing the same temporal behaviour in much of the sea level fluctuations. 
Figure 5 presented annual, semi-annual and 18.6-years amplitudes. The mean annual amplitude was $+5.90 \pm 1.15 \mathrm{~cm}$ from satellite altimetry data, the mean annual amplitude was $+4.32 \pm 0.90 \mathrm{~cm}$ from tide gauge data. The semi-annual and 18.6-year signals show similar values.
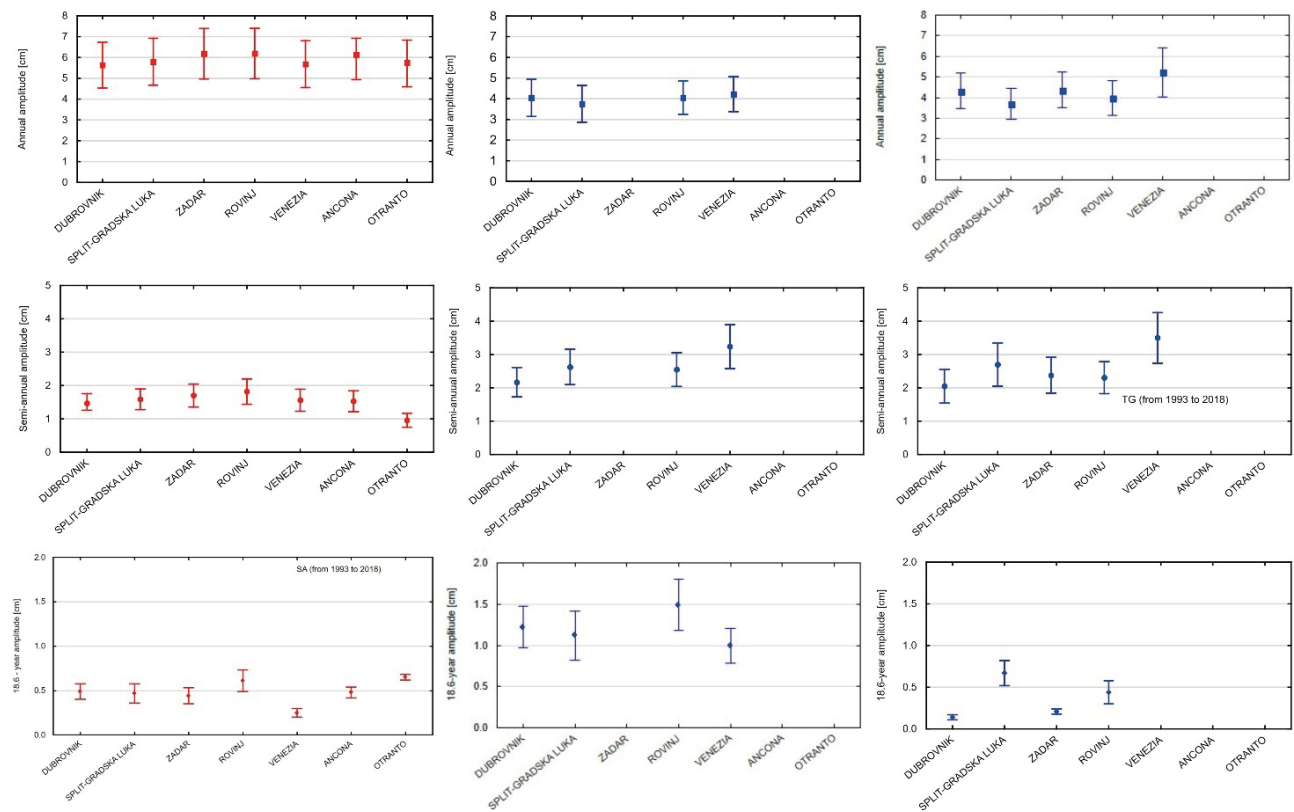

Fig. 5. Annual, semi-annual and 18.6-years amplitudes.

The first columns show amplitudes from satellite altimetry time series and second columns show amplitudes from tide gauge time series from beginning to 2018 .

The third column shows the amplitudes from tide gauge time series from 1993 to 2018

\subsection{GNSS Vertical Velocities}

The GNSS time series is estimated using robust methods of linear regression. We used the function model with annual and semi-annual periodic signals and a trend, as mentioned in [19], which can be expressed as follows [20]:

$$
f(t)=a+b t+\sum_{n-1}^{2} c_{n} \sin \left(\omega_{n} t+\varphi_{n}\right)+\varepsilon(t)
$$

where:

$f(t)$ - the time series,

$t$ - time,

$a, b-$ the constant and trend respectively,

$c_{n}$ - the annual and semi-annual amplitudes,

$\omega_{n}-$ the annual and semi-annual angular frequency,

$\varphi_{n}$ - the annual and semi-annual phase,

$\varepsilon(t)$ - the un-modelled residual term. 
In order to estimate the trend and the seasonal components, the least-squares method was used [21]. For the analysis of the time series, it is first necessary to determine the number of outliers and discontinuities (gaps and jumps). After eliminating or reducing the impact of undesirable factors, an examination of the linear relationship between variables (correlation), trend determination, and periodic signals (changes) is required in order to estimate the quality of the fitted model for observations [22]. GNSS time series should contain data from at least 3 years of the measurement period [23] (optimally it is 5 years) with daily resolution. The time series of vertical coordinates of 6 GNSS stations on the Adriatic coast were obtained from the Nevada Geodetic Laboratory [16] and SONEL [17]. The time-series data span is greater than 7 years (only for the PSAL GNSS station the time series was shorter, about 5 years), as it is recommended in order to result in reliable estimations of the velocities and their uncertainties, respectively (Fig. 6).
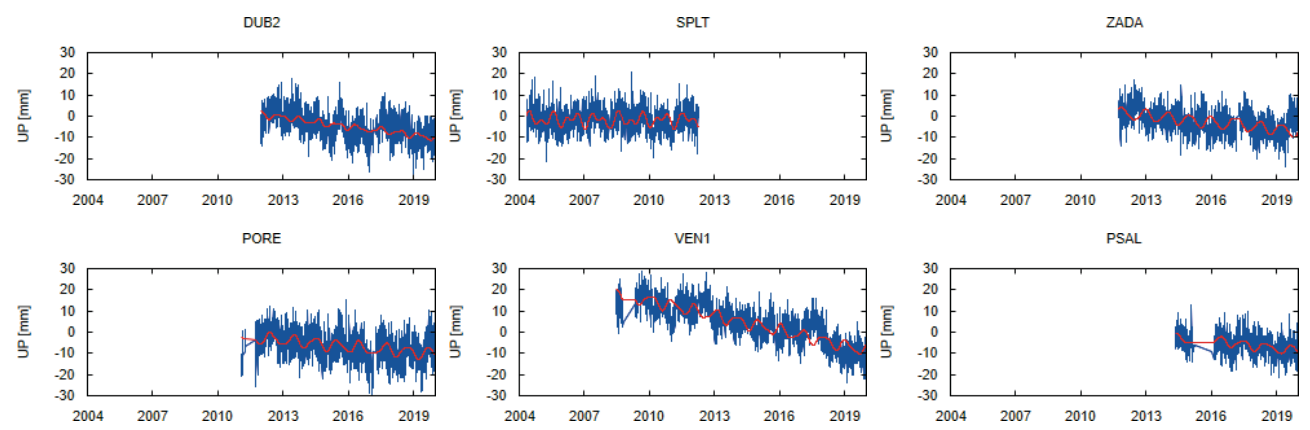

Fig. 6. The GNSS time series, original time series (seasonal, blue line) and function model (non-seasonal time series, red line)

\subsection{Verification of Vertical Crustal Movements Velocities}

For verification of vertical crustal movement velocities, linear trend estimates were compared derived from SA-TG with data from permanent GNSS stations. These stations are in reasonable proximity to the TG stations and began operation in the early 200s.

The vertical movements of the Earth's crust from the data of TG and SA is calculated by the below formula [24]:

$$
v_{h}=v_{S A}-v_{T G}
$$

where:

$v_{S A}$ - absolute change in sea level determined from altimetric data (referred to an ellipsoid),

$v_{T G}$ - relative change in mean sea level determined from TG observations,

$v_{h}-$ absolute vertical crustal movement (referred to an ellipsoid). 
The standard error of this movement is calculated with the use of the following formula:

$$
\sigma_{v_{h}}=\sqrt{\sigma_{v_{S A}^{2}}+\sigma_{v_{T G}^{2}}}
$$

$\sigma_{v_{h}}$ - the standard error of determination absolute vertical crustal movement,

$\sigma_{v_{S A}}$ - the standard error of determination change in sea level determined from altimetric data,

$\sigma_{v_{T G}}$ - the standard error of determination relative change in mean sea level determined from TG observations.

Table 3. Absolute vertical crustal movement derived from the approach combining satellite altimetry and tide gauge data against GNSS vertical velocities at the 6 co-located stations

\begin{tabular}{||l|c|c|c|c|c||}
\hline $\begin{array}{c}\text { TG_station/ } \\
\text { GNSS_station }\end{array}$ & $\begin{array}{c}\text { SA-TG velocity } \\
\text { [mm/yr] } \\
\text { (from beginning } \\
\text { to 2018) }\end{array}$ & $\begin{array}{c}\text { SA-TG velocity } \\
\text { [mm/yr] } \\
\text { (from 1993 } \\
\text { to } 2018)\end{array}$ & $\begin{array}{c}\text { GNSS from } \\
\text { SONEL } \\
\text { velocity } \\
\text { [mm/yr] }\end{array}$ & $\begin{array}{c}\text { GNSS from } \\
\text { this study } \\
\text { velocity } \\
\text { [mm/yr] }\end{array}$ & $\begin{array}{c}\text { Distance TG } \\
\text { to GNSS } \\
\text { [m] }\end{array}$ \\
\hline $\begin{array}{l}\text { Dubrovnik/ } \\
\text { DUB2 }\end{array}$ & $+1.60 \pm 0.32$ & $-0.79 \pm 0.41$ & $-2.11 \pm 1.33$ & $-1.49 \pm 0.01$ & 4167 \\
\hline $\begin{array}{l}\text { Split-Gradska } \\
\text { Luka/SPLT }\end{array}$ & $+2.58 \pm 0.32$ & $+0.86 \pm 0.40$ & $+0.45 \pm 0.68$ & $-0.08 \pm 0.02$ & 1 \\
\hline Zadar/ZADA & - & $+0.73 \pm 0.45$ & $-2.47 \pm 0.78$ & $-1.18 \pm 0.02$ & 1248 \\
\hline Rovinj/PORE & $+2.64 \pm 0.48$ & $+1.08 \pm 0.25$ & $-1.51 \pm 1.03$ & $-0.92 \pm 0.02$ & 16069 \\
\hline Venezia/VEN1 & $+0.66 \pm 0.31$ & - & $-1.78 \pm 0.73$ & $-2.38 \pm 0.03$ & 1384 \\
\hline Venezia/PSAL & $+0.66 \pm 0.31$ & - & $-1.73 \pm 0.88$ & $-1.41 \pm 0.03$ & 42 \\
\hline
\end{tabular}

Table 3 provides estimates of vertical land movements at the selected tide gauge sites. For comparison, GNSS vertical velocities from the analysed solution of NGL from SONEL network were obtained. Positive rate values indicate land uplift, while negative values indicate land subsidence. Only for the Split-Gradska Luka station was there a positive rate value indicating land uplift, while all the other stations had negative values, which points to land subsidence. In this study, all of the GNSS station had negative values indicating land subsidence.

Crust movements were well above zero in all tide gauges from the SA-TG data sets. The standard errors are in the range of $\pm 0.31 \mathrm{~mm} /$ year to $\pm 0.48 \mathrm{~mm} /$ year (from beginning to 2018) and of $\pm 0.25 \mathrm{~mm} /$ year to $\pm 0.45 \mathrm{~mm} /$ year (from 1993 to 2018). We have shown that the vertical movements of the Earth's crust around GNSS stations determined by other techniques are not the same. The uncertainty of velocity 
determinations based on GNSS data is bigger in comparison with combined SA minus TG data which ranges from $\pm 0.01 \mathrm{~mm} /$ year to $\pm 0.03 \mathrm{~mm} /$ year.

The results indicate that the velocities calculated in selected stations based on SA-TG data differ in sign relative to the values calculated based on GNSS data. A considerable difference was observed in the SPLT station $(+2.58 \mathrm{~mm} /$ year) where the standard error of velocity determination reached $\pm 0.32 \mathrm{~mm}$ /year in the SA-TG method and $-0.08 \pm 0.02 \mathrm{~mm} /$ year in the calculations based on GNSS data. A large discrepancy was also noted in the PORE station $(+2.64 \mathrm{~mm} /$ year $)$, where the standard error reached $\pm 0.48 \mathrm{~mm} /$ year in the SA-TG approach and $-0.92 \pm 0.02 \mathrm{~mm} /$ year in the calculations based on GNSS data. In the DUB2 station, the difference in the velocity was $+1.60 \mathrm{~mm} /$ year with a standard error of $\pm 0.32 \mathrm{~mm} /$ year in the SA-TG method and $-1.49 \pm 0.01 \mathrm{~mm} /$ year in the calculations based on GNSS data.

The differences between the values may be due to the non-tidal load on the earth's crust. Tidal and nontidal ocean mass changes also load the Earth's surface. Nontidal ocean mass variations, however, also exist and can also displace the Earth's surface at a level that should be observable in GPS coordinate data [25]. In addition, they can also be related to the differences between surface movements and ocean movements [26, 27]. In this study, the approach yielded standard errors between \pm 0.01 and $\pm 0.03 \mathrm{~mm} /$ year, in addition, was used the longest data span, which was available from the SONEL network.

\section{Discussion and Conclusions}

The sea level changes and the vertical crustal movement velocities were researched using tide gauge station sites in the area of the Adriatic Sea coast. The time series from tide gauges and from satellite altimetry were collected and the differences between them estimated. The vertical rates were compared with from nearby GNSS observations. More generally, we explored the influence of vertical land movements on differences in sea level trends in coastal areas. On the Croatian and Italian coasts, highly coherent regional patterns of sea level change appeared, with the trend $+3.30 \pm 0.32 \mathrm{~mm} /$ year from the satellite altimetry data.

The determination of vertical land movements is very important in order to investigate what factors influence the sea level change on a given coast and improve our knowledge about the causes [7].

The tide gauge observations provide the longest information about sea level changes, thus it is necessary to exploit long-term TG records in combination with satellite altimetry observations and precise GNSS observations. It might be assumed that in recent decades geophysical processes have become relatively more pronounced than in the evaluation of earlier observations. There could be several explanations for this, but it is clear that further data collection and the introduction of new methods and analysis are needed. For example, one such step would be greater 
collaboration with the InSAR community to investigate the potential applications of new data from this technique that are relevant for our research. The InSAR-based ground motion service uses active corner reflectors - transponders - as a central unit of the new method. In such a way, we can tie InSAR motions with velocities from GNSS if the transponders are located in the vicinity of the GNSS station or TG [24]. In summary, with a sufficiently long-time span reaching from 5 to 12 years, we were able to obtain reliable estimates for the vertical ground motion at the TG sites along the Adriatic Sea coasts. There is land subsidence on the coast of Croatia and Italy and the sea level is rising.

The results obtained can be used as source data for studying, contrasting, and constraining tectonic models of the region.

\section{References}

[1] Dodet G., Bertin X., Bouchette F., Gravelle M., Testut L., Wöppelmann G.: Characterization of sea-level variations along the metropolitan coasts of France: waves, tides, storm surges and long-term changes. Journal of Coastal Research, vol. 88 (special issue), 2019, pp. 10-24. https://doi.org/10.2112/SI88-003.1.

[2] Bradshaw E., Rickards L., Aarup T.: Sea level data archaeology and the Global Sea Level Observing System (GLOSS). GeoResJ, vol. 6, 2015, pp. 9-16. https://doi.org/10.1016/j.grj.2015.02.005.

[3] WCRP Global Sea Level Budget Group: Global sea-level budget 1993-present. Earth System Science Data, vol. 10, 2018, pp. 1551-1590. https://doi.org/ 10.5194/essd-10-1551-2018.

[4] Wöppelmann G., Pouvreau N., Simon B.: Brest sea level record: a time series construction back to the early eighteenth century. Ocean Dynamics, vol. 56(5-6), 2006, pp. 487-497. https://doi.org/10.1007/s10236-005-0044-z.

[5] Marcos M., Wöppelmann G., Matthews A. et al.: Coastal sea level and related fields from existing observing systems. Surveys in Geophysics, vol. 40(6), 2019, pp. 1293-1317. https://doi.org/10.1007/s10712-019-09513-3.

[6] Bitharis S., Ampatzidis D., Pikridas C., Fotiou A., Rossikopoulos D., Schuh H.: The role of GNSS vertical velocities to correct estimates of sea level rise from tide gauge measurements in Greece. Marine Geodesy, vol. 40(5), 2017, pp. 297-314. https://doi.org/10.1080/01490419.2017.1322646.

[7] Wöppelmann G., Marcos M.: Coastal sea level rise in southern Europe and the nonclimate contribution of vertical land motion. Journal of Geophysical Research: Oceans, vol. 117(C1), 2012. https://doi.org/10.1029/2011JC007469.

[8] Cazenave A., Dominh K., Ponchaut F., Soudarin L., Cretaux J.F., Le Provost C.: Sea level changes from Topex-Poseidon altimetry and tide gauges, and vertical crustal motions from DORIS. Geophysical Research Letters, vol. 26(14), 1999, pp. 2077-2080. https://doi.org/10.1029/1999GL900472. 
[9] Nerem R.S., Mitchum G.T.: Estimates of vertical crustal motion derived from differences of TOPEX/POSEIDON and tide gauge sea level measurements. Geophysical Research Letters, vol. 29(19), 2002, pp. 40-1-40-4. https://doi.org/ 10.1029/2002GL015037.

[10] Haigh I.D., Eliot M., Pattiaratchi C.: Global influences of the 18.61 year nodal cycle and 8.85 year cycle of lunar perigee on high tidal levels. Journal of Geophysical Research: Oceans, vol. 116(C6), 2011. https://doi.org/10.1029/2010JC006645.

[11] Wöodworth P.L., Player R.: The permanent service for mean sea level: An update to the 21st century. Journal of Coastal Research, vol. 19(2), 2003, pp. 287-295. http://www.jstor.org/stable/4299170.

[12] Pajak K., Kowalczyk K.: A comparison of seasonal variations of sea level in the southern Baltic Sea from altimetry and tide gauge data. Advances in Space Research, vol. 63(5), 2019, pp. 1768-1780. https://doi.org/10.1016/j.asr.2018.11.022.

[13] PSMSL: https://www.psmsl.org/ [access: 20.01.2020].

[14] AVISO: http://www.aviso.oceanobs.com [access: 15.01.2020].

[15] CMEMS: http://marine.copernicus.eu/services-portfolio/access-to-products/ [access: 15.01.2020].

[16] NGL (Nevada Geodetic Laboratory): http://geodesy.unr.edu [access: 15.01.2020].

[17] SONEL (Système d'Observation du Niveau des Eaux Littorales): https:// www.sonel.org/ [access: 15.01.2020].

[18] Garcia D., Vigo I., Chao B.F., Martinez M.C.: Vertical crustal motion along the Mediterranean and Black Sea coast derived from ocean altimetry and tide gauge data. Pure and Applied Geophysics, vol. 164(4), 2007, pp. 851-863. https://doi.org/10.1007/978-3-7643-8417-3_13.

[19] Cazenave A., Cabanes C., Dominh K., Mangiarotti S.: Recent sea level change in the Mediterranean Searevealed by Topex/Poseidon satellite altimetry. Geophysical Research Letters, vol. 28(8), 2001, pp. 1607-1610. https://doi.org/10.1029/2000GL012628.

[20] Avsar N.B., Jin S., Kutoglu H., Gurbuz G.: Sea level change along the Black Sea coast from satellite altimetry, tide gauge and GPS observations. Geodesy and Geodynamics, vol. 7(1), 2016, pp. 50-55. https://doi.org/10.1016/ j.geog.2016.03.005.

[21] Łyszkowicz A., Bernatowicz A.: Geocentric Baltic Sea level changes along the southern coastline. Advances in Space Research, vol. 64(9), 2019, pp. 1807-1815. https://doi.org/10.1016/j.asr.2019.07.040.

[22] Gazeaux J., Williams S., King M., Bos M. et al.: Detecting offsets in GPS time series: First results from the detection of offsets in GPS experiment. Journal of Geophysical Research: Solid Earth, vol. 118(5), 2013, pp. 2397-2407. https://doi.org/ 10.1002/jgrb.50152

[23] Ihde J., Augath W., Sacher M.: The Vertical Reference System for Europe. [in:] Drewes H., Dodson A.H., Fortes L.P.S., Sánchez L., Sandoval P. (eds.), Vertical Reference Systems, International Association of Geodesy Symposia, vol. 124, Springer. https://doi.org/10.1007/978-3-662-04683-8_64. 
[24] Kowalczyk K., Pajak K., Wieczorek B., Naumowicz B.: An Analysis of Vertical Crustal Movements along the European Coast from Satellite Altimetry, Tide Gauge, GNSS and Radar Interferometry. Remote Sensing, vol. 13(11), 2021, 2173. https://doi.org/10.3390/rs13112173.

[25] van Dam T., Collilieux X., Wuite J. et al.: Nontidal ocean loading: amplitudes and potential effects in GPS height time series. Journal of Geodesy, vol. 86, 2012, pp. 1043-1057. https://doi.org/10.1007/s00190-012-0564-5.

[26] Zygmunt M., Rajner M., Liwosz T.: Assessment of continental hydrosphere loading using GNSS measurements. Reports on Geodesy and Geoinformatics, vol. 101(1), 2016, pp. 36-53. https://doi.org/10.1515/rgg-2016-0020.

[27] Baker T.: Tidal deformations of the Earth. Science Progress (1933-), vol. 69(274), pp. 197-233. http://www.jstor.org/stable/43420600 [access: 29.06.2021]. 